Article

\title{
Finnish Mothers' Assessments of the Harmfulness of Childcare at Home on Occupational Careers: A Comparison of Twelve European Countries
}

\section{Sirpa Weckström}

Department of Social Research, University of Turku, Assistentinkatu 7, Turku 20500, Finland; E-Mail: sirpa.weckstrom@utu.fi; Tel.: +358-50-302-9753

Academic Editor: Martin J. Bull

Received: 31 August 2015 / Accepted: 12 November 2015 / Published: 25 November 2015

\begin{abstract}
It is generally believed that long periods of childcare at home deteriorate mothers' occupational careers. This study examined mothers' experiences regarding negative career consequences of full-time care of children at home, and of part-time work due to childcare. The focus was on Finland, a country that provides all mothers a financially compensated, longer-term childcare leave linked with unrestricted access to day care services. Experiences of Finnish mothers were compared with experiences of mothers in 11 other European countries. The data were based on European Social Survey (ESS) round 2, conducted in 2004 and 2005. In all of the studied countries, the majority of mothers assessed that taking care of children at home had not harmed their occupational careers. There was, however, a clear cross-country variation. Perceived career consequences for both types of care at home were least common in Finland. In most of the investigated countries, longer times spent with children at home increased the probability to perceive negative career consequences. In Finland, the difference was relatively small. Thus, as long as the focus is on mothers' perceptions, the longer-term childcare leave does not seem to markedly deteriorate Finnish mothers' careers.
\end{abstract}

Keywords: career consequences; childcare policy; child home care; mothers; part-time work

\section{Introduction}

During the last few decades, as a result of prolonged family leaves, the possibilities for working mothers to stay at home with their newborn children have improved in many European countries [1], 
including Finland where mothers are facilitated to stay at home until the child is three years old. At the same time, influenced by, e.g., globalization and the growing importance of market principles also in public sector organizations (e.g., [2,3]), demands faced by employees have increased. In many cases, this means that in order to cope with increased competition, an employee should constantly update her skills and knowledge base. This study focuses on self-assessed consequences of time spent with children at home on mothers' occupational careers. Despite debates in Europe regarding family leave opportunities and, in particular, the ways that mothers' careers are affected by various leave durations, perceptions of mothers have rarely been examined.

It is generally thought that generous family leave policies facilitate the attachment of women to paid work by preventing work exit. There are, however, concerns that very long leave periods may negatively affect mothers' careers [4,5]. Some studies suggest that while leaves extending up to about one year strengthen ties to the labor market, leaves extending up to two to three years may weaken the ties and erode human capital ([4], pp. 240-41; [6], p. 146). After the family leave period, a crucial circumstance is the availability of non-maternal care at a reasonable cost. A number of studies indicate that public provision of day care increases labor market participation among mothers (see, for example, [7-9]).

In the present study, mothers were asked whether they think that the times they have stayed at home full-time and at work part-time because they were taking care of their children at home have had negative consequences on their occupational career. Earlier studies regarding career-related consequences of motherhood have typically considered objectively measured outcomes such as the timing of post-birth employment, the effect of employment interruptions and transition to part-time work on mothers' earnings later in life, or, more generally, wage penalties related to motherhood (see, for example, [10-14]). These studies basically indicate that the way childcare policies are organized is important. In general, policies that support female employment have been associated with greater employment continuity and a smaller difference between the wages of mothers and non-mothers, in comparison to less supportive policies.

As outlined by the human capital approach (for example, [15-17]), work experience and education markedly affect an individual's career progression in terms of wages. During the child home care periods mothers normally do not accumulate work experience or participate in education, and therefore lower wages for mothers than for childless women have typically been associated with childcare at home. Yet, there are other reasons that may also contribute to mothers receiving lower wages than non-mothers. For examples: mothers may trade better earnings for more family-friendly jobs, or they can be discriminated against by employers [18], a mother may be less productive at work because of energy and effort spent at home [18], career ambitions for future mothers as compared to future non-mothers may differ (for example, [19]), and this could produce a wage difference before the child-related work interruptions. To varying degrees, these other reasons have been controlled for (for example, [20]). Still, the strength of having mothers' own interpretations of the importance of child-related work interruptions on their situation (the approach used in the present study) is that it differentiates child caring responsibilities in particular from other reasons that may prevent mothers from accomplishing career goals.

Because several factors intervene between the objective conditions and an individual's perceptions of these conditions, a subjective interpretation might not in all cases correlate with the objective situation [21]. As an example, varied values given to the two life domains may affect mothers' perceptions. Still, it is important to understand how career consequences are seen. Perceived negative 
consequences indicate how much mothers feel they sacrifice when they take time off for care [22], and this could have a bearing on various decisions regarding family and work, thereby affecting the society ${ }^{1}$.

How mothers assess career consequences related to childcare at home has rarely been explored. However, in a study by Ejrnæs [22] regarding Austria, Denmark, Hungary, Portugal, and the UK, it was found that mothers in Denmark assessed career consequences related to full-time care at home less negatively than mothers in the other investigated countries, which showed the advantages of a well-paid and protected employment leave and high childcare coverage. Included here are two more Nordic countries, Finland and Sweden, with corresponding conditions: paid parental leave and practically unrestricted access to day care services. However, what differentiates Finland from Denmark and Sweden is that its child home care allowance enables mothers to stay at home, with their job protected, until the child is three years old, i.e., a period that should (at least in theory) deteriorate human capital and consequently career progression ${ }^{2}$.

The two main aims of this study are to find out (a) whether self-assessed negative career consequences related to full-time care of children at home are more common in Finland than in Denmark and Sweden; and (b) how Finnish mothers do in a wider cross-country comparison. To broaden the understanding of mothers' perceptions regarding the harmfulness of domestic childcare, mothers who had worked part-time due to childcare needs were included in the investigation. In the earlier study, based on the same data [22], perceived negative career consequences were presented only for full-time care of children at home.

The reference countries represent different types of family leave and day care policies and different working patterns of mothers. In addition to the three Nordic countries, the following (reference) countries were included: Austria, Belgium, France, Germany, Greece, the Netherlands, Portugal, Spain, and the United Kingdom. To the investigation were selected mothers with children under 13 years old. These mothers had children and took care of them at home during the 1990s and early 2000s. Despite changes that occurred in national policies during this period, basic differences between the countries did not fade away. Main differences and similarities between childcare policies are exclusively taken into consideration here, and when these policies are discussed in more detail, the focus is around the year 2000. Through discussion and data analysis, this study discusses family leave and day care policies, and the possible importance of these policies on perceived negative career consequences.

\section{Childcare Policies and Expectations Regarding Perceived Career Consequences}

During child home care periods mothers do not accumulate work-related human capital, and can even experience skill depreciation, possibly delaying career progression. Childcare policies affect mothers' careers by influencing mothers' time outside of work. Also significant for subjectively assessed career consequences is the importance given to career progression and work position. In addition to the fact that mothers' orientations toward work vary (for example, [19]), various occupations

1 For example, there is some indication (though based on childless women) that the expected effect of children on occupational careers may affect the decision of some women to postpone or abandon childbearing (e.g., [23,24]).

2 In 2008, a longer-term leave was also introduced in Sweden. However, the benefit is available only in part of the municipalities [25]. In Denmark, some form of longer-term leave was introduced in 2002, but only a small number of mothers have used the benefit [26]. 
and organizations provide different possibilities to accumulate (or lose) human capital as well as different promotional opportunities. The manner in which family leave and day care policies are organized affects the possibilities for mothers to adjust the time they take care of their children at home in relation to their aims and the possibilities related to paid work. In particular, reasonably priced day care with long hours protect mothers from having to involuntarily withdraw from work, and enable them to choose full-time instead of part-time (hourly reduced) work. How career consequences are perceived has even been considered an indicator of mothers' capabilities for realizing their employment goals in different family policy regimes [22].

Even if opportunities and constrains related to family leave and day care policies are the focus in this study, they are not the only factors that are not the same in the countries studied and may affect work-care choices of the mothers, see e.g., [7,27]. Economic and labor market conditions as well as social and cultural norms of "good motherhood" also influence mothers' behavior, in particular the choice between full-time work and part-time work. It is important to note, however, that these other factors seldom affect mothers' choices distinctly from childcare policies. For example, it has been stated that in the part-time pattern (e.g., Germany and the UK) the causes and consequences of structural, cultural, and institutional explanations are highly mixed. Because the cultural understanding does not support mothers' full-time work, there are not any (or many) institutional supports for it in terms of childcare, and because no full-time based childcare is available, both parents cannot work full-time. Again, because of a cultural understanding that the mother is more responsible for childcare, it is the mothers who adjust their working time patterns according to the childcare options that are available. Further, since mothers are, for both cultural and institutional reasons, constrained to work part-time, labor markets also perceive them as a group that cannot commit to full-time work and are offering only part-time jobs to them ([27], pp. 148-49).

Characteristic of caring policies in the three Nordic countries included in this study is universalism (a Scandinavian/Nordic public care model [28], see also [29]). Nevertheless, Finland has been placed into a different family policy model than Sweden and Denmark (extensive family policy model), and into the same model (long parental leave family policy model) with Austria, Germany, and several eastern European countries including Hungary ( $c f$. [22]), despite the much higher availability and more reasonable cost of formal day care in Finland than in these other countries [30]. Moreover, Finland has been placed in the same category as such countries as Belgium and France [31]. Due to its unique combination of longer-term childcare leave and unrestricted access to day care services, Finland does not unambiguously cluster with any other country included in this investigation. Therefore, instead of setting expectations based on family policy classifications, the two fields of childcare policies (family leave and day care policies), as well as the possible importance of these policies on perceived career consequences of childcare at home, are discussed with the focus on differences and similarities between Finland and the other countries.

\subsection{Full-Time Care at Home}

Regarding childcare policies that support women's employment, Denmark, Finland, and Sweden may be regarded as forerunners [32]. Despite some variations in parental leave legislations [33,34], mothers are enabled to take care of their newborns at home for relatively long periods. After the parental 
leaves, all children are entitled to a public day care at a reasonable cost. However, what differentiates Finland from the other two Nordic countries is the much longer maximum leave period (Table 1). Whereas in Denmark and Sweden the maximum leave periods did not markedly exceed one year, the mothers included in Finland were entitled to choose a child home care allowance as an alternative for a public day care until the child was three years old ${ }^{3}$. The percentage of Finnish mothers using the leave extension has been high: In $2001,80 \%$ of mothers extended the home care period by at least a couple of months. Of these mothers, one-third remained on leave until the child was three or nearly three years old ([37], p. 191). In 2010, the allowance was paid to $52 \%$ of families having a child from nine months to two $(<3)$ years old [38].

Table 1. Characteristics of childcare policies around the year 2000.

\begin{tabular}{lccccccc}
\hline & \multicolumn{3}{c}{ Family Leave Opportunities } & \multicolumn{3}{c}{ Formal Public and Publicly Funded Care and } \\
Education Facilities
\end{tabular}

${ }^{a}$ Replacement of average female earnings during the first three months of the parental leave (the maternity leave period is typically well compensated in the studied countries); ${ }^{b}$ Coverage varies from $48 \%$ (Greece) to $99 \%$ (Belgium); Preschool hours (which do not necessarily correspond with opening hours) are typically free of charge; ${ }^{\mathrm{c}}$ FR: flat-rate benefit; ${ }^{\mathrm{d}}$ Total duration of leave was 15 months. After the twelve months of earnings-related compensation, parents were entitled to a flat-rate compensation for three months; ${ }^{\mathrm{e}}$ Maternity leave, parental leave, and a career break [39]; ${ }^{\mathrm{f}}$ Payment is available for part of the mothers; ${ }^{g}$ Payment is income tested and available for two years. Sources: Bradshaw and Finch [40]; De Henau, Meulders, and O’Dorchai [41,42]; Gornick and Meyers [4].

Payments targeted to families that do not enrol their children in public day care have been associated as having negative effects on individuals with respect to their labour market position and potential for career progression. By leading to long absences from the workforce, "cash for care" benefits may increase the risk of not getting a job, not being considered for advancement, and not developing one's qualifications $[35,43]$. These outcomes are basically in line with principles central to the human

3 In 1985, when the child home care allowance was introduced, the Centre Party in particular considered the benefit to be a compensation for the lack of services in rural areas [35]. In the 1990s, however, the demand side of childcare services was, for the most part, met [36]. 
capital approach; that is, negative career effects (lower wages) are mainly a consequence of lacking accumulation of human capital during non-participation and (if non-participation is long) skill depreciation.

Can it then be expected that negative career consequences are perceived more often by Finnish mothers as compared to Danish or Swedish mothers? Even if there is a variation regarding the extent to which objective and subjective indicators of the same phenomenon correspond with each other, a relationship typically exists [21]. Some suggestions can therefore be obtained from objectively measured outcomes. In a study by Gash [10], practically no wage penalties were observed for Finnish mothers, whereas small penalties were observed for Danish mothers, somewhat larger penalties were observed for mothers in the Netherlands and France, and the largest penalties observed were those of mothers in Germany and the United Kingdom (Sweden was not included). According to a recent study regarding Finnish married couples [44], maternity is associated with a wage reduction after returning to employment, but the association seems to exist for only a short time. A study regarding wage penalties in the Finnish private sector, however, suggests that there might be some negative effects for a somewhat longer time for those mothers who stayed more than two subsequent years at home when compared to non-mothers [20]. Three years after they returned to the labor market, a wage penalty was still observed for these mothers.

Another indication of the objective situation is attachment to paid work among the mothers. Based on employment statistics, Finnish mothers return to or enter into paid work quite soon after the child home care allowance period. Whereas the employment rate for mothers with children under three years old is among the lowest in Europe, for those mothers whose children are somewhat older, it is among the highest, see Table $2^{4}$. On the other hand, somewhat higher long-term unemployment rates have been found for mothers with children from three to six years old as compared to other mothers [36], suggesting that it might be difficult for some of the mothers to find a place in the labor market after the allowance period.

Table 2. Employment rates among mothers with the youngest child under 3 years old, 3 to 5 years old, and 6 to 16 years old in 2005 .

\begin{tabular}{cccc}
\hline & Age $<2$ & Age 3-5 & Age 6-16 \\
\hline Austria & 60.5 & 62.4 & 67.5 \\
Belgium & 63.8 & 63.3 & 56.9 \\
Denmark & 71.4 & 77.8 & 77.5 \\
Finland & 52.1 & 80.7 & 84.2 \\
France & 53.7 & 63.8 & 61.7 \\
Germany & 36.1 & 54.8 & 62.7 \\
Greece & 49.5 & 53.6 & 50.4 \\
Netherlands & 69.4 & 68.3 & 69.4 \\
Portugal & 69.1 & 71.8 & 65.4 \\
Spain & 45.1 & 47.9 & 50.9 \\
Sweden & 71.9 & 81.3 & 76.1 \\
UK & 52.6 & 58.3 & 67.7 \\
\hline
\end{tabular}

Source: Organisation for Economic Co-Operation and Development (OECD) [45].

4 Finnish mothers on a childcare leave, even if they have a work contract, are not counted as employed as they are in some other countries with very long parental leaves ([45], p. 47). Thus, the lower employment rate of Finnish mothers, when the youngest child is under three years of age, when compared with some other countries is related to varying definitions of the concept employed. 
Based on such objectively measured outcomes, the only group of Finnish mothers that might experience harm for a somewhat longer time is composed of those who have taken all or almost all of the available leave days. Since, however, mothers in Finland have unrestricted access to day care services and thus have the ability to adjust the time they care for their children at home to reflect their plans and opportunities related to career progression and position at work, it cannot be concluded with certainty that they should report perceived negative career consequences more often than mothers in the other two Nordic countries.

A brief look is next taken at childcare policies in the other reference countries. As shown in Table 1, the availability of care in Belgium and France is more widespread than in the rest of the investigated countries but not as complete as in the three Nordic countries. In France, the maximum duration of the leave period is as long as in Finland, but the flat-rate compensation is given only to those mothers who have more than one child (until the year 1994, more than two children). In Austria and Germany, the investigated mothers were entitled to a relatively long maximum leave period (around two and three years, respectively), and were thus protected from involuntary job loss for quite some time ${ }^{5}$. Inadequate access to day care services, however, decreased their opportunity to choose between a short and long work interruption. In the southern European countries, the Netherlands, and the United Kingdom, the investigated mothers were not entitled to financial compensation during the parental leave period (Table 1). Lacking compensation may increase the pressures for some mothers to quickly return to paid work, which should decrease the risk of human capital deprivation. This especially concerns countries with lower economic affluence. For example, in Portugal, the average low household incomes necessitate that women keep working or return to work after childbirth [9]. Lacking day care may, on the other hand, also result in some of the mothers unwillingly staying at home for a prolonged period, and especially when the maximum leave period is short, some of the mothers may end up quitting their earlier job.

A sufficient length of family leave linked with unrestricted access to day care services reduces involuntary job loss and facilitates the possibilities of mothers to adjust the time they stay at home with their aims and opportunities related to paid work. Therefore, in a wider cross-country comparison, self-assessed career consequences reported by Finnish mothers should be relatively rare. Yet, there is the possibility that circumstances specific to individual countries, particularly substitutions for public day care, interfere with this expectation. Especially in the southern European countries, many mothers turn to their own mothers or mothers-in-law in order to organize care for their children [47-49]. As an alternative, families may turn to private services. However, even when possible subsidies, benefits, and tax reductions are taken into consideration, fees for private services typically are relatively high (for example, [40]), and cannot be afforded by all families.

\subsection{Part-Time Work}

In several of the countries where full-time care is rare, mothers frequently work part-time. Particularly in the UK, Germany, and Austria, many mothers turn to part-time work, and in the

5 In the late 2000s, both Austria and Germany renewed their family leave legislation. The foremost changes concern financial incentives for mothers to return earlier to the labor market. Maximum leave periods are still long, but mothers are encouraged not to use the whole period [46]. 
Netherlands part-time work is practically the only way for mothers to participate in paid work [50] $]^{6}$ In Germany, for example, the tradition of part-time work as women's and mothers' forms of working, as well as day care systems that operate mainly on a part-time basis, create constraints on "choosing" full-time work at the same time as they provide mothers the opportunity to view part-time work as a feasible option and participate in it [27].

In Finland, labor markets are based on the norm of full-time work and there is a long tradition of full-time work among both mothers and fathers. Most mothers who return to work after the family leave period maintain the same level of working hours as prior to the leave period [52]. In this respect, Finland differs from the other two Nordic countries, especially Sweden, where mothers commonly reduce their working hours for a certain time [53,54]. In Sweden, motherhood (child-minding) was among the most common reasons for women to turn to part-time work already in the early 1990s, and it affected the decision to reduce working hours, especially among mothers who had a qualified job [55]. Part-time work among Swedish mothers has been facilitated by, for example, the especially flexible parental leave legislation, which states that mothers can save a part of the parental leave and use it to reduce working hours. After using the whole leave period, parents still have the right to work $75 \%$ of full-time until the child is eight years old. Various legislations in other studied countries also facilitate mothers to work part-time in their regular job (including Finland, where mothers may reduce their working hours), although these legislations were typically enacted later and less extensively than in Sweden $[1,4,54,56]$.

It is a distinctive characteristic for the included Nordic countries that there is a high availability of day care with long opening hours (Table 1). Long opening hours improve mothers' abilities to choose between full-time work and part-time work with nearly full hours. As an alternative to full-time work, and to slightly shorter working hours in a regular job, a mother can turn to a typical part-time job. Compared to full-time jobs, typical part-time jobs require lower qualifications and provide fewer opportunities for learning and formal training [57,58]. For example, in the UK, part-time work tends to be concentrated in low-paid and low-skill jobs linked with limited career progression possibilities [51]. On the other hand, not even a high-quality part-time job ensures that career opportunities are equivalent to those of a full-time job. Based on mothers in the UK, simply requesting reduced hours could lead to exclusion from promotion consideration [59] (see also, [60]).

In this study, freedom to choose between full-time and part-time work ( $c f$. day care services) is expected to reduce negative perceptions related to part-time work. Therefore, mothers in Finland are expected to report negative career consequences related to part-time work relatively rarely.

\section{Data and Methods}

The data of the present study are based on the European Social Survey (ESS) Round 2, conducted in 2004 and 2005. Twelve countries that represent different types of childcare policies and different working patterns of the mothers were selected from the over 20 countries included in the ESS. The sample consisted of women 20 to 50 years old who had their own, adopted, foster, or partner's

6 Lacking day care does not necessarily mean that a mother who works part-time would more willingly work full-time. In the UK, for example, even if a lack of affordable childcare appears to be the most important barrier to working full-time, there are also other reasons behind the choice of part-time work [51]. 
child(ren) under the age of 13 living in the same household. Only mothers who had participated in paid work at some point in their life were included. The criterion was that a mother had reported at least six months of continuous participation in either full-time or part-time work (over 19 hours per week). Besides employed mothers, those mothers who did not participate in paid work at the time of the interview were also included in the investigation. The selection criteria used here means that the voice of those mothers who had dropped out of employment, were staying home, or were facing unemployment or short temporary work contracts after the childcare period was also heard. In this respect, the present study differs from the earlier study based on the same data [22]. The numbers of investigated mothers were 207 in Austria, 157 in Belgium, 184 in Denmark, 263 in Germany, 198 in Greece, 201 in Finland, 225 in France, 133 in the United Kingdom, 240 in the Netherlands, 207 in Portugal, 139 in Spain, and 200 in Sweden.

The total time mothers had spent full-time at home caring for children was measured by the question: "Including any time spent on maternity or parental leave, around how long in total have you spent full-time at home because you were caring for your child(ren)?" The total time spent working part-time due to child caring was measured by the question: "Around how long in total, have you spent in part-time work rather than full-time work because you were caring for your child(ren)?" There were seven response categories for both of these questions: (1) no time at home full-time/no time at part-time work rather than full-time work because of children; (2) up to six months; (3) more than six months up to twelve months; (4) more than a year up to two years; (5) more than two years up to four years; (6) more than four years up to ten years; and (7) more than ten years.

Subjectively assessed career consequences were measured separately for full-time care and part-time work. In both cases the question was: "Do you think that this (full-time care at home/part-time work) has had negative consequences for your occupational career?" The answering categories were: (1) yes definitely; (2) yes probably; (3) no probably not; and (4) no definitely not.

Descriptive statistics were used to investigate how long on average mothers in the studied countries had taken care of their children at home, and how large a percentage of the mothers thought that childcare at home had negatively impacted their occupational career. Results are presented separately for full-time care at home and for part-time work. Regarding full-time care, the occurrences of perceived negative career consequences are reported for mothers who have spent less than one year, one to two years, two to four years, and more than four years with children at home. The age of the youngest child was a further point of interest. To facilitate the understanding of the reasons for different perceptions between the Nordic countries, a binary logistic regression analysis was used. All statistics have been calculated using weighted data (design weight), whereas numbers of respondents are given in a non-weighted format. The design weights are used to correct for slightly different probabilities of selection, thereby making the sample more representative of a "true" sample of individuals in each country [61].

\section{Results}

\subsection{Full-Time Care at Home}

A majority of mothers in all twelve investigated countries assessed that taking care of children at home had not harmed their occupational career (see Table 3). A clear cross-country variation is, 
however, observed. Perceived negative career consequences were least common in Finland, despite the long average time mothers had spent at home. Finland was closely followed by Denmark, and career consequences were relatively rare in Sweden as well. How long a mother had stayed at home seemed to be generally more decisive in Sweden than in the other two Nordic countries, in particular than in Finland (see Table 4). Except for Finland, in those countries where mothers were entitled to a long maximum leave period linked with monetary compensation, a relatively large proportion of mothers reported negative consequences (see results for Austria, Germany, and France, in Table 3) ${ }^{7}$.

Table 3. Average time spent full-time at home due to childcare and subjectively assessed career consequences.

\begin{tabular}{ccccc}
\hline & Full-Time at Home $(\mathbf{F T H}) * \mathbf{F T H}>\mathbf{1}$ & & Negative Career Consequences ** \% \\
\hline UK & 5.06 & 5.34 & UK & 43.2 \\
Finland & 4.77 & 4.81 & Germany & 42.3 \\
Austria & 4.76 & 5.02 & Austria & 38.4 \\
Germany & 4.72 & 4.92 & France & 37.5 \\
Sweden & 4.46 & 4.53 & Greece & 27.2 \\
France & 4.01 & 4.27 & Portugal & 26.6 \\
Denmark & 3.84 & 3.93 & Sweden & 25.0 \\
Netherlands & 3.75 & 4.16 & Spain & 24.0 \\
Belgium & 3.43 & 3.85 & Netherlands & 23.9 \\
Greece & 3.13 & 3.81 & Belgium & 21.6 \\
Spain & 3.00 & 3.73 & Denmark & 19.0 \\
Portugal & 2.66 & 2.93 & Finland & 17.6 \\
\hline
\end{tabular}

* (1) no time at all; (2) less than six months; (3) from six months to a year; (4) from a year to two years; (5) from two to four years; (6) from four to ten years; (7) more than 10 years; ** Definitely or probably negative career consequences; FTH $>1$ includes only those mothers who have stayed full-time at home because of childcare.

In most countries, longer times spent with children at home increased the risk of perceiving negative career consequences. In those countries where mothers were entitled to a longer-term childcare leave, experiences were not especially sensitive to the duration of time spent at home, at least when only those mothers who had spent longer than one year at home were considered (see Table 4). However, French mothers were an exception in that longer times spent at home led to markedly higher amounts of negative consequences compared to shorter times spent at home.

7 Except for the UK, in those countries where a short maximum leave period was followed by inadequate day care services, the number of mothers typically reporting a relatively short leave because of children at home and career consequences related to these short home care periods were small or intermediate (see Table 3). Even if some of the mothers concerned were still at home, many of them had seemingly succeeded in finding a day care substitution. In the UK, some mothers had perhaps ended up dropping out of an earlier job and had not found a corresponding new one. Along with the lengthening of the maximum leave period [1], the risk for an involuntary job loss should have decreased. 
Table 4. Perceived negative career consequences among mothers with different times spent full-time at home.

\begin{tabular}{ccccc}
\hline & Up to 1 Year * \% n & $\mathbf{1}$ to 2 Years \% n & 2 to 4 Years \% n & More than 4 Years \% n \\
\hline Austria & $16.7(26)$ & $39.5(38)$ & $34.6(56)$ & $47.9(76)$ \\
Belgium & $4.3(69)$ & $29.1(24)$ & $37.5(8)$ & $48.5(33)$ \\
Denmark & $14.9(67)$ & $17.5(57)$ & $13.9(36)$ & $50.0(18)$ \\
Finland & $6.9(29)$ & $17.5(40)$ & $17.1(70)$ & $23.3(60)$ \\
France & $13.0(77)$ & $25.8(31)$ & $42.8(50)$ & $73.7(49)$ \\
Germany & $25.5(48)$ & $39.5(36)$ & $54.9(71)$ & $43.0(94)$ \\
Greece & $19.8(81)$ & $16.7(20)$ & $26.3(23)$ & $55.5(28)$ \\
Netherlands & $12.8(105)$ & $26.6(16)$ & $45.0(19)$ & $35.1(68)$ \\
Portugal & $19.4(130)$ & $33.3(20)$ & $44.4(14)$ & $77.7(8)$ \\
Spain & $13.5(51)$ & $17.7(17)$ & $69.3(13)$ & $27.8(18)$ \\
Sweden & $10.3(29)$ & $11.5(61)$ & $29.2(72)$ & $52.9(34)$ \\
UK & $42.9(23)$ & $22.2(15)$ & $28.5(19)$ & $52.2(67)$ \\
\hline
\end{tabular}

* Does not include mothers who have spent no time at all at home because of children.

One possible explanation for the relatively uncommon career consequences among Finnish mothers could be found in overly optimistic evaluations of those mothers who are presently or have just recently been at home with their children. From this perspective, perceived negative career consequences would become more obvious when mothers have confronted the reality after the child home care periods. An inspection of the data does not, however, support this explanation. Whereas $17.6 \%$ of all mothers in Finland reported negative career consequences, the corresponding rate was $25.8 \%$ for mothers whose youngest child was under three years old, $18.2 \%$ for mothers whose youngest child was three to six years old, and $10.3 \%$ for mothers whose youngest child was over six years old (see Table 5$)^{8}$.

Table 5. Perceived negative career consequences of mothers.

\begin{tabular}{ccccc}
\hline & All Mothers \% & $\begin{array}{c}\text { Youngest Child 0-2 } \\
\text { Years Old \% }\end{array}$ & $\begin{array}{c}\text { Youngest Child 3-6 } \\
\text { Years Old \% }\end{array}$ & $\begin{array}{c}\text { Youngest Child over 6 } \\
\text { Years Old \% }\end{array}$ \\
\hline UK & 43.2 & 53.3 & 53.6 & 34.3 \\
Germany & 42.3 & 43.4 & 39.6 & 45.5 \\
Austria & 38.4 & 35.6 & 41.7 & 36.5 \\
France & 37.5 & 30.0 & 33.9 & 44.8 \\
Greece & 27.2 & 21.2 & 29.4 & 28.3 \\
Portugal & 26.6 & 12.3 & 33.4 & 32.1 \\
Sweden & 25.0 & 19.6 & 26.7 & 27.5 \\
Spain & 24.0 & 12.4 & 36.7 & 21.3 \\
Netherlands & 23.9 & 17.1 & 29.2 & 25.6 \\
Belgium & 21.6 & 16.2 & 20.9 & 25.9 \\
Denmark & 19.0 & 28.6 & 18.7 & 12.2 \\
Finland & 17.6 & 25.8 & 18.2 & 10.3 \\
\hline
\end{tabular}

8 Based on the used cross-sectional approach, one cannot conclude how perceptions of individual mothers have changed over time. There is the possibility that practically all mothers with older children had never perceived negative career consequences. Yet, the uncommonly perceived career consequences among these mothers might suggest that consequences even out quite well in the course of time. 
Mothers whose youngest child is over six years old are especially interesting for certain reasons regarding perceived career consequences. Firstly, these mothers should be able to better assess actualized, rather than expected, career consequences compared to mothers who were still at home or had just recently returned to paid work. Secondly, careers of these mothers should have had more time to recover from possible detrimental effects related to child-related work interruptions. However, in most countries a considerable part of mothers in this category reported negative career consequences (Table 5).

At odds with earlier findings regarding family wage gaps [11,12], negative consequences were reported more commonly by Swedish mothers as compared to Finnish and Danish mothers. Results of a closer inspection (a binary logistic regression analysis) on this category of mothers for the three Nordic countries are shown in Table 6. Controlling for time spent at home, number of children, years of education, and mothers' age did not decrease the difference between Sweden and Finland (Models 2 and 3). A marked explanation for the difference between Sweden and Denmark seems to be different durations of time spent with children at home.

Table 6. Perceived negative career consequences related to full-time care at home for mothers in Denmark, Finland, and Sweden with the youngest child over 6 years old ${ }^{\text {a }}$.

\begin{tabular}{|c|c|c|c|}
\hline & Model 1 & Model 2 & Model 3 \\
\hline Total length & & $0.940 * * *$ & $1.036 * * *$ \\
\hline \multicolumn{4}{|l|}{ No. of children: } \\
\hline 1 & & & -0.273 \\
\hline 2 & & & 0.052 \\
\hline 3 or more & & & 0 \\
\hline Mother's age & & & 0.064 \\
\hline Years of education & & & 0.140 \\
\hline \multicolumn{4}{|l|}{ Country: } \\
\hline Denmark & $-0.994 *$ & -0.549 & -0.684 \\
\hline Finland & $-1.203 * *$ & $-1.644 * *$ & $-1.750 * *$ \\
\hline Sweden & 0 & 0 & 0 \\
\hline
\end{tabular}

${ }^{*} p<0.05 ; * * p<0.01 ; * * * p<0.001{ }^{\text {a }}$ The numbers of mothers were 66 in Denmark, 78 in Finland and 80 in Sweden.

Overall, this supplementary analysis did not provide any further explanation for the difference between Sweden and Finland. On the other hand, one cannot make fully reliable conclusions based on such low numbers of mothers. In future, in particular the significance of education could be examined in more detail. Besides work experience, education is another marked source of human capital important to career development in terms of wages [15-17], and it is known that those mothers in Finland who use the whole childcare leave (until the child is three years old) are less educated than those mothers who use just part of it (see e.g., [62]). The level of education could also be taken into consideration, instead of relying only on the duration of education. 


\subsection{Part-Time Work}

Regarding part-time work, once again perceived negative career consequences were rarest for mothers in Finland followed by those in Denmark (see Table 7). Thus, mothers in these countries reported career consequences less often than mothers in Portugal, Spain, and Greece, i.e., the other countries where part-time work was relatively rare. The value for Sweden differed clearly from that for Germany, but not that much from the value for some of those other countries where a majority of mothers had turned to part-time work and where part-time work periods were relatively long ${ }^{9}$. Based on the above results, the importance of a greater freedom of choice attains overall support.

Table 7. Average time mothers spent at part-time work due to childcare and subjectively assessed career consequences.

\begin{tabular}{ccccc}
\hline & $\begin{array}{c}\text { Time Spent at Part-Time } \\
\text { Work (PTW) * PTW }>\mathbf{1}\end{array}$ & & $\begin{array}{c}\text { Negative Consequences } \\
\text { on the Career ** \% }\end{array}$ \\
\hline Netherlands & 3.96 & 5.39 & Germany & 43.9 \\
Austria & 3.70 & 4.91 & France & 37.3 \\
Germany & 3.49 & 4.85 & Portugal & 36.2 \\
Sweden & 3.36 & 4.84 & UK & 36.0 \\
UK & 3.28 & 5.02 & Netherlands & 31.5 \\
Belgium & 2.97 & 5.04 & Austria & 30.4 \\
France & 2.91 & 5.08 & Spain & 30.3 \\
Denmark & 1.99 & 4.37 & Sweden & 27.0 \\
Spain & 1.82 & 3.53 & Greece & 26.2 \\
Greece & 1.62 & 3.59 & Belgium & 22.4 \\
Finland & 1.56 & 3.87 & Denmark & 13.0 \\
Portugal & 1.48 & 2.63 & Finland & 5.2 \\
\hline
\end{tabular}

* (1) no time at all; (2) less than six months; (3) from six months to a year; (4) from a year to two years; (5) from two to four years; (6) from four to ten years; (7) more than 10 years; ** Definitely or probably negative career consequences. The percentages (and numbers) of mothers who had worked part-time due to childcare from all mothers with work experience were as follows: Austria 69\% (142), Belgium 48\% (76), Germany 60\% (159), Denmark 29\% (54), Spain 31\% (43), Finland 19\% (39), France 44\% (100), UK 55\% (73), Greece 24\% (47), Netherlands 68\% (163), Portugal 29\% (59), and Sweden $61 \%$ (122). PTW $>1$ means that those mothers who had never participated in part-time work because of childcare were excluded.

\section{Discussion}

During the last few decades, a clear improvement has occurred in many European countries regarding the possibilities for mothers to stay at home with their newborn children. In some countries, the maximum leave period has been prolonged to an extent that should, at least theoretically, negatively affect mothers' careers. One of these countries is Finland.

9 As to the Netherlands, a possible explanation is the commonness of part-time work. Part-time work is available in all types of occupations and in all educational groups, and there is practically no difference between the hourly wages for full-time and part-time workers $[63,64]$. 
Despite the "cash for care" benefits which have been linked to negative effects with respect to labor market positions and possibilities for career progression (e.g., $[35,43]$ ), mothers in Finland reported negative career consequences related to full-time domestic care of children less frequently than mothers in the other investigated countries. Career consequences were regarded as relatively rare even among those mothers who had stayed at home for more than four years. Among Swedish mothers, career consequences were relatively rare, but the confidence on the absence of career consequences decreased more clearly when a mother had spent altogether more than two years at home full-time. The difference between Finland and Sweden is basically in line with political discourses related to leave extensions. Whereas in Finland the focus has (until recently) been on a freedom of families to choose between home care and institutionalized care, in Sweden there has been a wider concern regarding a fading equality between women and men, i.e., a matter that has to do with mothers' careers [65]. The causal role of political discourses affecting experiences of individuals can be discussed and challenged, and the causality is not necessarily straightforward. Yet, attitudes at the macro level (and among individuals) have possibly in part affected how mothers in these two countries evaluated career consequences related to long home care periods, thereby increasing the difference. That is, when long-term home care is generally expected to risk career progression, mothers may, perhaps, more easily link a delayed career progression with it. A further difference between Finland and Sweden was the higher commonness of part-time work in Sweden. For Swedish mothers, the two types of perceived career consequences were related, and this could suggest that some of those mothers who had turned to part-time work directly after a (long) full-time care period could not discern with certainty which one was the foremost reason for a delayed career progression and, therefore, held them both as responsible. Also, selection of mothers with regard to very long home care periods might vary between the countries. For example, mothers' attachment to paid work just before the home care period may vary.

The older the youngest child was, the less mothers perceived negative career consequences in Finland and Denmark, but the outcome was vice versa in Sweden and the negative consequences increased slightly the older the youngest child was. A possible explanation for the different outcome in Sweden as compared to the other two Nordic countries is that occupational careers of Swedish mothers had not, in their own opinion, recovered with time in the same way as in the other two countries. However, to verify this outcome, a longitudinal database (and a larger number of mothers) would be needed. Based on mothers' assessments, the child home care allowance does not appear to much harm occupational careers of Finnish mothers. When thinking about the importance of a leave extension, it is important to be aware of the conditions that enhanced its popularity during the period considered here. There was an especially strong increase in unemployment in Finland during the recession years in the early 1990s, from around 3\% in 1990 to almost $17 \%$ in 1994 [66,67]. Even if the economy recovered quite well, the low unemployment levels prior to the recession were never again attained. For example, in the year 2000, the unemployment rate was $10 \%$ [67]. Of those mothers in Finland who for a long time received the child home care allowance, many were already weakly attached to paid work before the home care period. Therefore, it is possible that for some of the investigated mothers the actual choice was between the child home care allowance and the unemployment allowance, instead of the child home care allowance and paid work, see ([68], p. 55). The Finnish childcare policies signal to mothers that childcare at home is a normatively appropriate behavior until the youngest child is three years old. When there is a lack of jobs, the possibility to prolong child home care provides an 
alternative identity to an identity of (a long-term) unemployed and this alternative identity has, perhaps, been regarded as beneficial later in a job search situation by some of the mothers. An inadequate supply of jobs has, to some extent, eventually prolonged periods spent at home with children. However, because a vast majority of mothers in Finland use at least part of the leave extension, the long home care periods and the relatively rarely reported negative career consequences cannot be explained simply by some mothers' difficulties to find jobs.

Longer times spent at home with children increased the probability of perceiving negative career consequences in most of the studied countries. This result is basically in line with expectations based on human capital theory, and suggests that long home care in particular may harm career prospects of mothers. Interestingly, however, in most of those countries (including Finland) where mothers were entitled to a very long maximum leave period, perceived career consequences were not especially sensitive to the duration of time a mother had stayed at home, at least when the consideration was restricted to those mothers who had stayed more than one year at home. In this respect, France was an exception as perceived career consequences increased markedly with an increase of time spent at home with children. A prolonged absence from paid work may (in addition to the human capital issue) send an unfavorable signal to employers concerning a mother's continued orientation towards work [69]. When access to a monetarily compensated longer-term childcare leave is available for all mothers (as is the case in Finland), a long absence is perhaps a weaker sign of orientation towards family instead of paid work than it is in those countries where the benefit depends on the number of children (as is the case in France) $)^{10}$.

What should be kept in mind when interpreting these results is that the total number of years spent at home because of childcare is not the same as the length of continuous absence from paid work. Mothers may (or may not) enter employment between childbirths, and also these care/work patterns may differ between the countries. For example, in Finland, the mothers who give birth to the second child within three years after the first child are spilt into two groups; the first half starts a new maternity leave directly from childcare leave of the first child, whereas the second half has a break in care for employment, study, or other reasons before the second child is born [62]. Whether or not the mother is employed between the childbirths and for how long may affect perceived career consequences through affecting human capital accumulation/skill depreciation. It would be interesting to include this aspect in the considerations in the future.

With respect to part-time work, the smallest perceived negative career consequences were again found in Finland, followed by Denmark. Besides varying durations of part-time work, a further difference between Finland and Sweden could be a dissimilar selection of mothers to part-time work. That is, when work time reduction is a norm rather than an exception as is the case in Finland, also some of those mothers may reduce their working hours who have high ambitions related to career progression and/or whose jobs are such that even a small work time reduction might threaten career

10 Further, it has been put forward that a very generous family leave legislation may be accompanied by employer discrimination against mothers as a group (for Germany, see Reference [70]). However, no evidence for this was found in Finland. 
progression $^{11}$. Perceived negative career consequences were overall relatively uncommon in Finland, whether considering full-time care at home or part-time work.

There are a few limitations that should be taken into consideration when reflecting on the present results. Firstly, the relatively low numbers of mothers limits the possibilities to make generalizations within the investigated countries, and therefore the results obtained should be seen as suggestive rather than conclusive. Secondly, in this work, career consequences were studied in terms of a difference between a perceived reality and an imaginary life-situation with no child-related work interruptions. The self-assessed career consequences thus refer to a subjective (in)equality between women with and without children. A generalization to subjective (in)equalities between mothers and fathers or more generally women and men in the investigated countries is, however, not achievable. Even in those countries where childcare policies are in general supportive of employment, some effects on gender equality may be negative. Generous leave schemes may lead to employer discrimination and negative effects on all women of childbearing age, especially when the leave days are taken almost solely by the mothers [71,72]. Overall, small self-assessed career consequences in the present study refer to perceived equality between women with and without children ${ }^{12}$, but do not indicate the non-existence of harmful effects in other respects.

\section{Summary and Conclusions}

Self-assessed consequences of time spent at home with children on the occupational careers of mothers were investigated in this work. Of special interest was Finland, a country with a long tradition of employment-supportive childcare policies, but providing differing access to a financially compensated longer-term childcare leave than the other two Nordic countries included in the study. Payments targeted to families that do not enroll their children in public day care have been associated with negative effects for individuals with respect to labor market possibilities and career progression.

Regarding the cross-country comparison, mothers in Finland non-commonly reported self-assessed negative career consequences related to full-time at-home care. Based on subjectively assessed career consequences, a leave extension in connection with otherwise employment-supportive childcare policies does not seem to markedly deteriorate careers of Finnish mothers. The current system in Finland allows mothers to take plans and possibilities related to career progression and work position into consideration when choosing the length of the home care period. This probably explains in part the relative rareness of perceived career consequences among those mothers who had stayed at home for a very long time. Perceived career consequences might not in all cases correspond with the objective situation. However, they indicate how much mothers feel they sacrifice when they take time off for care, and this might have a bearing on mothers' decisions related to family and work. In Finland, for

11 Finnish mothers also have a legal right to reduce their working hours until the child is around 8 years old (until the end of the second school year of the child). There are, however, certain work-related obstacles that hinder mothers from reducing working hours. One of these is a concern that a work time reduction may endanger their position in the workplace [52].

12 In this context, (in)equality is from the viewpoint of mothers rather than all women. A broader understanding of subjective (in)equality could be achieved by including non-mothers in the consideration. 
example, assessing career consequences as non-existent or short-term might have a bearing on the popularity of the child home care allowance.

The obtained results further suggest that the possibility of mothers to choose full-time instead of part-time work (considering such important options as day care services of high availability, high coverage and long opening hours) may reduce the likelihood of mothers experiencing negative consequences linked with part-time work, at least when part-time work is relatively uncommon as it is in Finland.

In summary, the findings regarding the two main aims (see Introduction) of this study are: (a) Finnish mothers do not report self-assessed negative career consequences relating to full-time care of children at home more often than mothers in the other two included Nordic countries; and (b) Finnish mothers do well in a wider cross-country comparison: in spite of mothers' long leave possibilities, Finnish mothers seem to be much more seldom worried than mothers in other countries about the harmfulness of the childcare leave. Do these two main findings then have any relevance on policy making in Finland? Until now, the child home care allowance system has been under threat only once. In 2013, the Finnish government prepared a bill where mothers' rights to the leave were cut by a year and this year was instead reserved for fathers [73]. The reform was justified by views that it promotes mothers' employment and career while also promoting gender equality. As far as the focus is on career consequences of the leave scheme and on mothers' perceptions, according to the results obtained, the decision of the government not to give the bill to the parliament seems appropriate. In case a similar change of the scheme is considered or implemented at some point in future, it would be good to consider mothers' views regarding negative career consequences besides paying attention on the other objectives aimed at by the reform.

Finally, there is a marked diversity in the distributions of the child home care periods, with or without interruptions, of the mothers. Nevertheless, the importance of a long leave scheme on self-assessed career consequences seems to vary markedly between the studied countries. It would be of interest to consider more carefully the reasons behind this variation. The various outcomes of this study overall suggest the way for further research in the future.

\section{Acknowledgments}

The author would like to thank the anonymous referees for their helpful comments.

\section{Conflicts of Interest}

The author declares no conflict of interest.

\section{References}

1. Kimberly Morgan. "Caring Time Policies in Western Europe: Trends and Implications." Comparative European Politics 7 (2009): 37-55.

2. Christopher Hood. "The 'New Public Management' in the 1980s: Variations on a Theme." Accounting, Organizations and Society 20 (1995): 93-109.

3. Jaakko Koivumäki. "Uusi Julkisjohtaminen ja Työelämän Muutokset 1990-luvulla: Lähenivätkö Julkisen ja Yksityisen Sektorin Palkansaajien Työelämäkokemukset (New Public Management 
and the Changes of Working Life in the 1990's-Did the Working Life Experience of Civil Servants and Private Sector Employees Converge)?” Hallinnon tutkimus 3 (2005): 14-31. Available online: http://elektra.helsinki.fi/se/h/0359-6680/24/3/uusijulk.pdf (accessed on 18 November 2015).

4. Janet Gornick, and Marcia Meyers. Families that Work. Policies for Reconciling Parenthood and Employment. New York: Russell Sage Foundation, 2003.

5. Marit Rönsen, and Marianne Sundström. "Family Policy and After-birth Employment among New Mothers-A Comparison of Finland, Norway and Sweden.” European Journal of Population 18 (2002): 121-52.

6. Organisation for Economic Co-Operation and Development (OECD). "Balancing Work and Family Life. Helping Parents into Paid Employment.” In OECD Employment Outlook 129-66. Paris: OECD, 2001, chap. 4. Available online: http://www.oecd.org/social/familiesandchildren/2079435.pdf (accessed on 18 November 2015).

7. Olli Kangas, and Tine Rostgaard. "Preferences or Institutions? Work-Family Life Opportunities in Seven European Countries.” Journal of European Social Policy 17 (2007): 240-56.

8. Marianne Simonsen. "Price of High-Quality Daycare and Female Employment." Scandinavian Journal of Economics 112 (2010): 570-94.

9. Wilfred Uunk, Matthijs Kalmijn, and Ruud Muffels. "The Impact of Young Children on Women's Labor Supply. A Reassessment of Institutional Effects in Europe.” Acta Sociologica 48 (2005): 41-62.

10. Vanessa Gash. "Sacrificing Their Careers for Their Families? An Analysis of the Penalty to Motherhood in Europe.” Social Indicators Research 93 (2009): 569-86.

11. Susan Harkness, and Jane Waldfogel. "The Family Gap in Pay: Evidence from Seven Industrialised Countries." Research in Labor Economics 22 (2003): 369-414.

12. Joya Misra, Michelle Budig, and Stephanie Moller. "Reconciliation Policies and the Effects of Motherhood on Employment, Earnings and Poverty." Journal of Comparative Policy Analysis: Research and Practice 9 (2007): 135-55.

13. Wendy Sigle-Rushton, and Jane Waldfogel. "Motherhood and Women's Earnings in Anglo-American, Continental European, and Nordic Countries." Feminist Economics 13 (2007): 55-91.

14. Haya Stier, and Noah Lewin-Epstein. "Welfare Regimes, Family-supportive Policies and Women's Employment along the Life-course.” American Journal of Sociology 106 (2001): 1731-60.

15. Gary S. Becker. Human Capital: A Theoretical and Empirical Analysis with Special Reference to Education. New York: National Bureau of Economic Research, 1964.

16. Gary S. Becker, and Barry R. Chiswick. "Education and the Distribution of Earnings." American Economic Review 56 (1966): 358-69.

17. Jacob Mincer, and Solomon Polachek. "Family Investment in Human Capital: Earnings of Women." Journal of Political Economy 82 (1974): 76-108.

18. Michelle J. Budig, and Paola England. "The Wage Penalty for Motherhood." American Sociological Review 66 (2001): 204-25.

19. Catherine Hakim. "Women, Careers, and Work-Life Preferences." British Journal of Guidance \& Counselling 34 (2006): 279-94.

20. Sami Napari. "Is There a Motherhood Wage Penalty in the Finnish Private Sector?" Labour 24 (2010): 55-73. 
21. Trevor Lee, and Robert Marans. "Objective and Subjective Indicators: Effects of Scale Discordance on Interrelationships." Social Indicators Research 8 (1980): 47-64.

22. Anders Ejrnæs. "The Impact of Family Policy and Career Interruptions on Women's Perceptions of the Negative Occupational Consequences of Full-Time Home Care." European Societies 13 (2011): 239-56.

23. Ariane Kemkes-Grottenthaler. "Postponing or Rejecting Parenthood? Results of a Survey among Female Academic Professionals.” Journal of Biosocial Science 35 (2003): 213-26.

24. Anneli Miettinen. "Voluntary or Involuntary Childlessness? Socio-Demographic Factors and Childlessness Intentions among Childless Finnish Men and Women Aged 25-44." Finnish Yearbook of Population Research XLV (2010): 5-24.

25. Guðný Eydal, and Tine Rostgaard. "Gender Equality Revisited-Changes in Nordic Childcare Policies in the 2000s." Social Policy \& Administration 45 (2011): 161-79.

26. Minna Rantalaiho. "Kvoter, Valgfrihet, Fleksibilitet. Indre Spenninger i den Nordiske Familliepolitikken." In Latitude, Freedom of Choice, Flexibility. Inner Tensions in Nordic Family Policy. Copenhagen: Nordisk Information för Kunskap om Kön (NIKK), 2009.

27. Milla Salin. 'Opportunities, Constraints and Constrained Opportunities-A Study on Mothers' Working Time Patterns in 22 European Countries." In Finnish Yearbook of Population Research. XVIX 2014 Supplement. Helsinki: The Population Research Institute, 2014.

28. Francesca Bettio, and Janneke Plantenga. "Comparing Care Regimes in Europe." Feminist Economics 10 (2004): 85-113.

29. Bent Greve. "What Characterise the Nordic Welfare State Model?" Journal of Social Sciences 3 (2007): 43-51.

30. Thomas Boje, and Anders Ejrnæs. "Policy and Practice: The Relationship between Family Policy Regime and Women's Labor Market Participation in Europe.” International Journal of Sociology and Social Policy 32 (2012): 589-605.

31. Karin Wall. "Leave Policy Models and the Articulation of Work and Family in Europe: A Comparative Perspective.” In International Review of Leave Policies and Related Research 2007. Employment Relations Research Series No. 80. Edited by Peter Moss and Karin Wall. London: Department for Business, Enterprise and Regulatory Reform, 2007, pp. 25-43.

32. Gosta Esping-Andersen. Social Foundations of Postindustrial Economies. Oxford: Oxford University Press, 1999.

33. Anita Haataja. "Pohjoismainen Ansaitsija-Hoivaajamalli-Ruotsin ja Suomen Perhevapaajärjestelmän Vertailu (Nordic Breadwinner-Caretaker Models-Comparison of Sweden and Finland)." 2006. Available online: http://www.julkari.fi/bitstream/handle/10024/ 112062/Selv200643.pdf?sequence=1 (accessed on 18 November 2015).

34. Elina Pylkkänen, and Nina Smith. "The Impact of Family-Friendly Policies in Denmark and Sweden on Mothers' Career Interruptions due to Childbirth.” IZA Discussion Paper No. 1050, Forschungsinstitut zur Zukunft der Arbeit (IZA), Bonn, Germany, 2004. Available online: http://ftp.iza.org/dp1050.pdf (accessed on 18 November 2015).

35. Anne Lise Ellingsæter. "Cash for Childcare. Experiences from Finland, Norway and Sweden." In International Policy Analysis. Berlin: Friedrich Ebert Stiftung, 2012. 
36. Anita Haataja. "Outcomes of the Two 1990s Family Policy Reforms at the Turn of the 2000s in Finland." Yearbook of Population Research in Finland 41 (2005): 5-27.

37. Organisation for Economic Co-Operation and Development (OECD). Babies and Bosses: Reconciling Work and Family Life: Canada, Finland, Sweden and the United Kingdom. Paris: OECD, 2005, vol. 4.

38. Kela. Kelan Lapsiperhe-etuustilasto (Benefits for Families with Children). Helsinki: Kela Statistics, 2010. Available online: http://www.kela.fi/it/kelasto/kelasto.nsf/alias/Perhe_10_pdf/ \$File/Perhe_10.pdf (accessed on 18 November 2015).

39. Laura Merla, and Fred Deven. "Belgium." In International Review of Leave Policies and Related Research 2006. Employment Relations Research Series No. 57. Edited by Peter Moss and Margaret O'Brien. London: Department of Trade and Industry, 2006, pp. 69-77.

40. Jonathan Bradshaw, and Naomi Finch. A Comparison of Child Benefit Packages in 22 Countries. Research Report No. 174. Leeds: Corporate Document Services, 2002.

41. Jérôme De Henau, Danièle Meulders, and Síle O'Dorchai. "Parents' Care and Career. Comparing Parental Leave Policies." In Social Policies, Labor Markets and Motherhood: A Comparative Analysis of European Countries. Edited by Daniela Del Boca and Cecilie Wetzels. Cambridge: Cambridge University Press, 2007, pp. 63-106.

42. Jérôme De Henau, Danièle Meulders, and Síle O’Dorchai. "Making Time for Working Parents: Comparing Public Childcare Provision." In Social Policies, Labor Markets and Motherhood: A Comparative Analysis of European Countries. Edited by Daniela Del Boca and Cecilie Wetzels. Cambridge: Cambridge University Press, 2007, pp. 28-51.

43. Åsa Nelander. Vårdnadsbidrag_En Tillbakagång i Svensk Familjepolitik. Report No. 5/2007. Stockholm: Arbetarrörelsens Tankesmedja, 2007.

44. Jenni Kellokumpu. "Essays on work and fertility". In VATT Publications 69. Helsinki: Government Institute for Economic Research, 2015.

45. Organisation for Economic Co-Operation and Development (OECD). Babies and Bosses: Reconciling Work and Family Life: A Synthesis of Findings from OECD Countries. Paris: OECD, 2007, vol. 5. Available online: http://www.oecd.org/els/family/babiesandbosses-reconcilingwork andfamilylifeasynthesisoffindingsforoecdcountries.htm (accessed on 18 November 2015).

46. Sigrid Leitner. "Germany Outpaces Austria in Childcare Policy: The Historical Contingencies of 'Conservative' Childcare Policy.” Journal of European Social Policy 20 (2010): 456-67.

47. Bruno Arpino, Chiara Pronzato, and Lara Tavares. "All in the Family: Informal Childcare and Mothers' Labor Market Participation.” ISER Working Paper Series No. 2010-24, Institute for Social \& Economic Research, Colchester, UK, 2010. Available online: https:// www.iser.essex.ac.uk/files/iser_working_papers/2010-24.pdf (accessed on 18 November 2015).

48. Council of Europe. "Council of Europe Family Policy Database 2009." Available online: http://www.coe.int/t/dg3/familypolicy/Source/3_4_3\%20Informal\%20child\%20care\%20systems.pdf (accessed on 18 November 2015).

49. Nota Kyriazis. "Women's Flexible Work and Family Responsibilities in Greece." In Gender Inequalities in Southern Europe. Women, Work and Welfare in 1990's. Edited by María González, Teresa Jurado and Manuela Naldini. London: Routledge, 2000, pp. 35-53. 
50. Eurostat. Reconciling Work and Family Life in the EU25 in 2003. Employment Rates Lower and Part-time Rates Higher for Women with Children. Newsletter 49/2005. Luxembourg: Eurostat Press Office, 2005. Available online: europa.eu/rapid/press-release_STAT-05-49_en.pdf (accessed on 18 November 2015).

51. Vidhya Alakeson. The Price of Motherhood: Women and Part Time Work. London: Resolution Foundation, 2012. Available online: http://www.resolutionfoundation.org/wp-content/uploads/ 2014/08/The-price-of-motherhood-women-and-part-time-work.pdf (accessed on 18 November 2015).

52. Anna-Maija Lehto, and Hanna Sutela. Työolojen Kolme Vuosikymmentä. Työolotutkimusten Tuloksia 1977-2008 (Three Decades of Working Conditions. Results from Quality of Work Life Surveys 1977-2008). Helsinki: Tilastokeskus (Statistics Finland), 2008.

53. Eurofound. Parental Leave in European Companies. Luxembourg: Office for Official Publications of the European Communities, 2007. Available online: http://www.eurofound.europa.eu/pubdocs/ 2006/87/en/1/ef0687en.pdf (accessed on 18 November 2015).

54. Organisation for Economic Co-Operation and Development (OECD). Starting Strong II: Early Childhood Education and Care, Annex E, Sweden. Paris: OCED, 2006. Available online: http://www.unicef.org/lac/spbarbados/Implementation/ECD/StartingStrongII_OECD_2006.pdf (accessed on 18 November 2015).

55. Per Båvner. "Half Full or Half Empty? Part-Time Work and Well-Being among Swedish Women.” Ph.D. Dissertation, Series No. 49, Swedish Institute for Social Research, University of Stockholm, Stockholm, Sweden, 4 May 2001.

56. Janneke Plantenga, and Chantal Remery. Reconciliation of Work and Private Life: A Comparative Review of Thirty European Countries. Luxembourg: Office for Official Publications of the European Communities, 2005. Available online: http://www.cecot.es/harmonitzacio/documentacio/estudi\% 20CE.pdf (accessed on 18 November 2015).

57. Eurofound. "Part-time Work in Europe." 2007. Available online: http:/www.eurofound.europa.eu/ ewco/reports/TN0403TR01/TN0403TR01.pdf (accessed on 18 November 2015).

58. Colette Fagan, and Brendan Burchell. Gender, Jobs and Working Conditions in the European Union. Luxembourg: Office for Official Publications of the European Communities, 2002. Available online: http:/www.eurofound.europa.eu/pubdocs/2002/49/en/1/ef0249en.pdf (accessed on 18 November 2015).

59. Sonia Liff, and Kate Ward. "Distorted Views Through the Glass Ceiling: The Construction of Women's Understandings of Promotion and Senior Management Positions." Gender, Work and Organization 8 (2001): 19-36.

60. Janet Smithson. "Full-Timer in a Part-Time Job: Identity Negotiation in Organizational Talk." Feminism \& Psychology 15 (2005): 275-93.

61. ESS EduNet. "Weighting the ESS Data." 2013. Available online: http://essedunet.nsd.uib.no/ cms/userguide/weight/ (accessed on 18 November 2015).

62. Anita Haataja, and Vesa-Pekka Juutilainen. Kuinka Pitkään Lasten Kotihoitoa? Selvitys Äitien Lastenhoitojaksoista kotona 2000-luvulla (How Long Home Care of Children? A Report Regarding the Periods Mothers have Taken Care of Their Children at Home during 2000s). Työpapereita 58. Helsinki: Kela, 2014. Available online: http://hdl.handle.net/10138/45390 (accessed on 18 November 2015). 
63. Harald Bielenski, Gerhard Bosch, and Alexandra Wagner. Working Time Preferences in Sixteen European Countries. Dublin: European Foundation for the Improvement of Living and Working Conditions (Eurofound), 2002. Available online: http://www.eurofound.europa.eu/pubdocs/2002/ 07/en/1/ef0207en.pdf (accessed on 18 November 2015).

64. Siv Gustafsson, Eiko Kenjoh, and Cecile Wetzels. "Employment Choices and Pay Differences Between Non-standard and Standard Work in Britain, Germany, Netherlands and Sweden." Discussion Papers 01-086/3, Tinbergen Instituut, Amsterdam, The Netherlands, 2001. Available online: http://papers.tinbergen.nl/01086.pdf (accessed on 18 November 2015).

65. Heikki Hiilamo, and Olli Kangas. Trap for Women or Freedom to Choose? Political Frames in the Making of Child Home Care Allowance in Finland and Sweden. Publications of the Department of Social Policy A: 18/2006. Turku: University of Turku, 2006.

66. Organisation for Economic Co-Operation and Development (OECD). OECD Employment Outlook. Statistical Annex. Paris: OECD, 2000. Available online: http://www.oecd-ilibrary.org/ docserver/download/8100041 e.pdf?expires $=1448205607 \& \mathrm{id}=\mathrm{id} \&$ accname $=$ ocid195730\&checksu $\mathrm{m}=\mathrm{ECF} 35481 \mathrm{D} 0 \mathrm{AC} 22 \mathrm{E} 125 \mathrm{CB} 175 \mathrm{D} 64667 \mathrm{CF} 3$ (accessed on 18 November 2015).

67. Organisation for Economic Co-Operation and Development (OECD). OECD Employment Outlook. Statistical Annex. Paris: OECD, 2010. Available online: http:/www.keepeek.com/Digital-AssetManagement/oecd/employment/oecd-employment-outlook-2010/statistical-annex_empl_outlook2010-6-en\#page1 (accessed on 18 November 2015).

68. Johanna Lammi-Taskula, Minna Salmi, and Sanna Parrukoski. Työ, Perhe ja Tasa-arvo (Employment, Family and Gender Equality). Report No. 55. Helsinki: Sosiaali-ja Terveysministeriö (Ministry of Social Affairs and Health), 2009.

69. Marie Evertsson, and Ann-Zofie Duvander. "Parental Leave-Possibility or Trap? Does Family Leave Length Effect Swedish Women's Labor Market Opportunities?" European Sociological Review 27 (2011): 435-50.

70. Markus Gangl, and Andrea Ziefle. "Motherhood, Labor Force Behavior and Women's Careers: An Empirical Assessment of the Wage Penalty for Motherhood in Britain, Germany and the United States." Demography 46 (2009): 341-69.

71. Nabanita Datta Gupta, and Nina Smith. "Children and Career Interruptions: The Family Gap in Denmark." Economica 69 (2002): 609-29.

72. Nabanita Datta Gupta, Nina Smith, and Mette Verner. "The Impact of Nordic Countries Family Friendly Policies on Employment, Wages and Children." Review of Economics of the Household 6 (2008): 65-89.

73. Valtioneuvosto. "Rakennepoliittinen Ohjelma Talouden Kasvuedellytysten Vahvistamiseksi ja Julkisen Talouden Kestävyysvajeen Umpeen Kuromiseksi (Structural Reform Programme Geared to Boost the Growth Potential of the Economy and Reduce the Sustainability Gap)." 2013. Available online: http://valtioneuvosto.fi/rakenneuudistus/rakennepoliittinen-ohjelma? (accessed on 18 November 2015).

(C) 2015 by the authors; licensee MDPI, Basel, Switzerland. This article is an open access article distributed under the terms and conditions of the Creative Commons Attribution license (http://creativecommons.org/licenses/by/4.0/). 